\title{
PENGGUNAAN MODEL PEMBELAJARAN KOOPERATIF TIPE NUMBERED HEAD TOGETHER (NHT) PADA PEMBELAJARAN MATEMATIKA UNTUK MENINGKATKAN MOTIVASI BELAJAR DAN HASIL BELAJAR SISWA KELAS IV
}

\author{
Tri Utami ${ }^{1}$, Firosalia Kristin ${ }^{2}$, Indri Anugraheni ${ }^{3}$ \\ ${ }^{1}$ Pendidikan Guru Sekolah Dasar, Universitas Kristen Satya Wacana, 292013522@student.uksw.edu \\ ${ }^{2}$ Pendidikan Guru Sekolah Dasar, Universitas Kristen Satya Wacana, firosalia.kristin@staff.uksw.edu \\ ${ }^{3}$ Pendidikan Guru Sekolah Dasar, Universitas Kristen Satya Wacana, indri.anugraheni@staff.uksw.edu
}

\section{INFO ARTIKEL \\ Riwayat Artikel: \\ Diterima: 13-04-2018 \\ Disetujui: 21-04-2018 \\ Kata Kunci: \\ Numbered Head \\ Together (NHT), \\ Matematika, \\ Motivasi Belajar, \\ Hasil Belajar}

\begin{abstract}
ABSTRAK
Abstrak: Tujuan penelitian ini untuk meningkatkan motivasi dan hasil belajar siswa kelas IV SD Negeri Genting 01 pada pembelajaran matematika menggunakan model pembelajaran kooperatif tipe NHT. Jenis Penelitian ini adalah penelitian tindakan kelas dengan subjek semua siswa kelas IV melalui II siklus. Teknik pengumpulan data menggunakan tes dan nontes. Rata--rata nilai motivasi belajar siswa pada kondisi awal 43,15, Siklus I 60,7 dan Siklus II 83,95.Rata-rata nilai hasil belajar siswa pada kondisi awal 54,15, pada Siklus I 75,75 dan Siklus II 89,25. Dapat disimpulkan bahwa penggunaan model pembelajaran kooperatif tipe NHT dapat meningkatkan motivasi belajar dan hasil belajar matematika pada siswa kelas IV SD Negeri Genting 02.

Abstract: The main purpose of the research is to increase student's motivation and academic achievment of fourth grade at SD Negeri Genting 01 of mathematic using Numbered Head Together of cooperative learning model. This research is Classroom Action Research with the subject all of students at fourth grade through 2 cycles. Data collection is done by using test and non test techniques. An average of learning motivation at initial condition showed 43,15, in cycle I 60,7 and cycle II 83,95. An average of students academic achievment at initial condition showed 54,15 in cycle I 75,75 and at cycle II 89,25. It was concluded that used Numbered Head Together cooperative learning model can increase students motivation and academic achievment of fourth grade at SD Negeri Genting 01 .
\end{abstract}

\section{A. LATAR BELAKANG}

Ideologi bangsa berupa Pancasila dan landasan konstitusional Undang-Undang Dasar Negara Republik Indonesia Tahun ajaran 1945 merupakan landasan pendidikan di Indonesia. Standar isi dan standar kompetensi lulusan menjadi dasar pengembangan kurikulum dengan arah pengembangan sesuai dengan Kurikulum Tingkat Satuan Pendidikan (KTSP) yang masih berlaku di Indonesia sampai saat ini (Depdiknas, 2016:416). Kriteria Ketuntasan Minimal (KKM) merupakan standar kompetensi lulusan yang harus dicapai oleh peserta didik. Kurikulum SD/MI memuat 7 mata pelajaran yang salah satunya adalah matematika Pada umumnya peserta didik menganggap bahwa mata pelajaran matematika merupakan mata pelajaran yang paling sulit (Boeree, 2008:29) . Math Phobia atau ketakutan terhadap matematika merupakan perasaan yang dimiliki oleh sebagian besar peserta didik yang takut dan tidak berminat belajar matematika sehingga mengakibatkan rendahnya motivasi belajar dan berdampak kepada rendahnya hasil belajar yang diperoleh siswa.

Berdasarkan pendapat Boeree (2008:29) peserta didik beranggapan bahwa mata pelajaran yang paling sulit adalah mata pelajaran matematika. Math Phobia atau ketakutan terhadap matematika merupakan perasaan yang dimiliki oleh sebagian besar peserta didik yang takut dan tidak berminat belajar matematika sehingga mengakibatkan rendahnya motivasi belajar dan berdampak kepada rendahnya hasil belajar yang diperoleh siswa. Paradigma yang menganggap matematika sebagai mata pelajaran yang paling sulit juga terjadi pada siswa kelas 4 SD Negeri Genting 01. Motivasi belajar adalah perasaan atau dorongan dalam kegiatan belajar yang ada pada setiap peserta didik untuk mencapai tujuan belajar yang dikehendaki. Motivasi belajar sangat penting dimiliki oleh peserta didik karena sangat berpengaruh terhadap hasil belajar yang akan diperoleh siswa. Adanya motivasi belajar yang tinggi akan menumbuhkan minat belajar siswa atau keinginan yang besar uuntuk melakukan kegiatan belajar. 
Motivasi yang diperoleh anak akan mempengaruhi perkembangan bakat yang dimiliki anak (Djamarah 2011:200). Dengan memiliki motivasi belajar peserta didik akan mempunyai keinginan dan semangat untuk mengikuti kegiatan pembelajaran, mengerjakan tugas dengan baik dan menyelesaikan kegiatan-kegiatan yang dapat menunjang untuk mencapai tujuan yang diinginkan.

Menurut Anugraheni (2017:657) Model pembelajaran merupakan pola yang digunakan sebagai pedoman dalam merencakan pembelajaran di kelas, termasuk dalam penyusunan kurikulum, menyusun materi, menentukan tujuan pembelajaran , menentukan langkah-langkah pembelajaran , pengelolaan kelas dan lingkungan dalan pembelajaran. Agar tidak terjadi kesalahpahaman tentang definisi NHT, maka perlu dijelaskan bahwa NHT merupakan sebuah variasi belajar dalam diskusi kelompok yang dapat mempengaruhi pola interaksi peserta didik. Nur (2011:78) berpendapat bahwa model pembelajaran NHT adalah sebuah variasi diskusi dalam kelompok dengan ciri khasnya guru menunjuk seorang siswa dalam setiap kelompok untuk mewakili kelompoknya.

Pembelajaran matematika dengan menggunakan model pembelajaran Numbered Head Together (NHT) sangat membantu siswa untuk menghilangkan Math Phobia serta untuk meningkatkan motivasi dan hasil belajar siswa. Menurut kristin, (2016:91) Baik tidaknya peningkatan hasil belajar siswa hanya didukung oleh kemauan siswa yang mau belajar dengan baik, tetapi juga metode pebelajaran yang digunakan guru juga sangat berpengaruh.

Motivasi adalah suatu keinginan yang dimiliki setiap individu untuk melakukan suatu perbuatan untuk mencapai tujuan yang dikehendaki (Hakim, 2000:26). Motivasi juga dapat dijadikan sebagai faktor pendorong yang dapat mempengaruhi timbulnya rasa semangat pada setiap individu untuk melakukan hal-hal yang membawa dirinya menjadi lebih baik. Menurut Kristin (2016:77) Belajar adalah suatu perubahan tingkah laku yang relatif permanen sebagai hasil dari pengalaman. Motivasi belajar merupakan kekuatan (power motivation) daya pendorong (driving force) atau alat pembangun kesediaan dan keinginan yang kuat dalam diri peserta didik untuk belajar secara aktif, kreatif, efektif, inovatif dan menyenangkan dalam rangka perubahan perilaku baik dalam aspek kognitif, afektif maupun psikomotor (Hanafiah \& Suhana, 2010)

Hasil belajar adalah cerminan tingkat keberhasilan atau pencapaian tujuan yang diinginkan pada suatu proses belajar yang telah dilaksanakan dan diakhiri dengan proses evaluasi. Hasil belajar merupakan hasil yang diperoleh seseorang dari aktivitas yang dilakukan dan mengakibatkan terjadinya perubahan tingkah laku (Kristin, 2016:78).

Peneliti mencoba menawarkan model pembelajaran kooperatif yang sesuai dengan kebutuhan siswa. Dengan merumuskan 1) Bagaimana Model pembelajaran Kooperatife Tipe Numered Head Together (NHT) dapat meningkatkan motivasi dan hasil belajar siswa pada mata pelajaran Matematika di kelas 4 SD Negeri Genting o1 Semester 1 Tahun 2017/2018? 2) Apakah penerapan Model pembelajaran Kooperatife Tipe Numered Head Together (NHT) dapat meningkatkan motivasi dan hasil belajar siswa pada mata pelajaran Matematika di kelas 4 SD Negeri Genting 01 Semester 1 Tahun 2017/2018? 3) Apakah penerapan Model pembelajaran Kooperatife Tipe Numered Head Together (NHT) dapat meningkatkan motivasi dan hasil belajar siswa pada mata pelajaran Matematika di kelas 4 SD Negeri Genting O1 Semester 1 Tahun 2017/2018?

Tujuan dari penelitian ini 1) Mendeskripsikan langkah-langkah penerapan Model pembelajaran Kooperatife Tipe Numered Head Together (NHT) pada mata pelajaran Matematika di kelas 4 SD Negeri Genting o1 Semester 1 Tahun 2017/2018 2) Meningkatkan motivasi belajar siswa dengan menerapan Model pembelajaran Kooperatife Tipe Numered Head Together (NHT) pada mata pelajaran Matematika di kelas 4 SD Negeri Genting 01 Semester 1 Tahun 2017/2018 3) Meningkatkan hasil belajar siswa dengan menerapan Model pembelajaran Kooperatife Tipe Numered Head Together (NHT) pada mata pelajaran Matematika di kelas 4 SD Negeri Genting 01 Semester 1 Tahun $2017 / 2018$

Berdasarkan latar belakang masalah di atas, maka peneliti melakukan penelitian tentang penggunaan model pembelajaran kooperatif tipe Numbered Heads Together (NHT) pada pembelajaran matematika untuk meningkatkan motivasi dan hasil belajar siswa kelas 4 SD negeri genting 01. Dari hasi pengamatan yang dilakukan guru kelas 4 SD Negeri Genting 01 terdapat beberapa permasalahan pembelajaran Matematika, diantaranya guru cenderung menggunakan metode ceramah, siswa masih beranggapan bahwa matematika adalah pelajaran yang sulit dan menjenuhkan, siswa cenderung pasif dan rendahnya motivasi belajar siswa pada pelajaran matematika.

\section{B. METODE PENELITIAN}

Jenis penelitian yang digunakan adalah penelitian tindakan kelas (PTK). Penelitian tindakan kelas ini memiliki ciri khas dengan tindakan dan mempunyai tujuan untuk memperbaiki proses belajar mengajar dikelas. Model PTK dalam penelitian ini menggunakan model spiral, yang dikemukakan oleh C.Kemmis dan Mc.Taggart, $\mathrm{R}$ dalam Arikunto (2010:137). Pada penelitian ini setiap siklusnya terdiri dari empat tahap, yaitu perencanaan (planning), tindakan (acting), pengamatan(observing), dan refleksi (reflecting)

Subyek penelitian ini adalah siswa kelas IV SD Negeri Genting 01 yang berjumlah 20 siswa. Teknik pengumpulan data melalui observasi, angket dan tes evaluasi. Instrumen pengumpulan data yang digunakan 
adalah lembar observasi, lembar angket dan lembar tes evaluasi. Analisis data dilakukan dengan analisis deskriptif komparatif. Variabel dalam penelitian ini terdiri dari variabel model pembelajaran Kooperatif tipe Numered Head Together (NHT) sebagai variabel terikat dan variabel motivasi belajar serta hasil belajar sebagai variabel terikat.

\section{HASIL DAN PEMBAHASAN}

\section{Hasil}

TABEL 1

HASIL PERBANDINGAN MOTIVASI BELAJAR KONDISI AWAL, SIKLUS I, SIKLUS II

\begin{tabular}{|c|c|c|c|c|c|c|c|c|}
\hline \multirow[t]{2}{*}{$\begin{array}{l}\mathbf{N} \\
\mathbf{o}\end{array}$} & \multirow[t]{2}{*}{$\begin{array}{c}\text { Kateg } \\
\text { ori }\end{array}$} & \multirow{2}{*}{$\begin{array}{c}\text { Int } \\
\text { erv } \\
\text { al }\end{array}$} & \multicolumn{2}{|c|}{$\begin{array}{c}\text { Kondisi } \\
\text { awal }\end{array}$} & \multicolumn{2}{|c|}{ Siklus I } & \multicolumn{2}{|c|}{ Siklus II } \\
\hline & & & $\mathbf{F}$ & $\begin{array}{c}\mathbf{P} \\
(\%)\end{array}$ & $\mathbf{F}$ & $\begin{array}{c}\mathbf{P} \\
(\%)\end{array}$ & $\mathbf{F}$ & $\begin{array}{c}\mathbf{P} \\
(\%)\end{array}$ \\
\hline 1 & $\begin{array}{l}\text { Sangat } \\
\text { Tinggi }\end{array}$ & $\begin{array}{c}79 \\
- \\
96\end{array}$ & 1 & $5 \%$ & 6 & $30 \%$ & 17 & $85 \%$ \\
\hline 2 & Tinggi & $\begin{array}{c}61 \\
- \\
78\end{array}$ & 3 & $15 \%$ & 4 & $20 \%$ & 3 & $15 \%$ \\
\hline 3 & Sedang & $\begin{array}{c}43 \\
- \\
60\end{array}$ & 2 & $10 \%$ & 7 & $35 \%$ & - & - \\
\hline 4 & Rendah & $\begin{array}{c}24 \\
- \\
42 \\
\end{array}$ & 14 & $70 \%$ & 3 & $15 \%$ & - & - \\
\hline \multicolumn{3}{|c|}{ Jumlah } & 20 & $\begin{array}{c}100 \\
\%\end{array}$ & 20 & $\begin{array}{c}100 \\
\%\end{array}$ & 20 & $\begin{array}{c}100 \\
\%\end{array}$ \\
\hline \multicolumn{3}{|c|}{ Rata-rata } & \multicolumn{2}{|c|}{43,15} & \multicolumn{2}{|c|}{60,7} & \multicolumn{2}{|c|}{83,95} \\
\hline
\end{tabular}

Pada tabel diatas dapat dilihat bahwa motivasi siswa pada kondisi awal, siklus I dan siklus II mengalami peningkatan. Peningkatan motivasi belajar siswa dari yang sangat tinggi pada kondisi awal 5\% menjadi $30 \%$ pada siklus I sedangkan pada siklus II meningkat menjadi $85 \%$. Telah terbukti dengan menggunakan model pembelajaran kooperatif tipe Numbered Head Together (NHT) dapat meningkatkan motivasi belajar pada siswa kelas IV SD Negeri Genting 01.

Berdasarkan hasil penelitian dapat dilihat bahwa terdapat peningkatan motivasi belajar siswa dalam pembelajaran matematika. Pada siklus I terlihat beberapa siswa pasif dalam diskusi kelompok bahkan beberapa siswa yang pasif merupakan siswa yang tercatat hasil belajarnya masih dibawah KKM. Ketika sebagian siswa berdiskusi untuk dapat mengerjakan soal yang diberikan guru, siswa yang masih pasif terlihat asyik bermain dan sebagian siswa menggambar. Setelah melakukan refleksi pada siklus I kemudian dilakukan perbaikan dalam siklus II. Pada siklus II terihat terdapat peningkatan motivasi belajar siswa. Ketika guru menyampaikan materi pembelajaran siswa aktif untuk bertanya mengenai penjelasan yang masih kurang jelas, begitupun ketika dalam berdiskusi kelompok setiap kelompok terlihat aktif berdiskusi untuk mendapatkan jawaban yang tepat. Selain itu, juga terlihat beberapa siswa membantu siswa yang masih belum paham dengan cara memberikan penjelasan secara berulang-ulang.

Meningkatnya motivasi belajar dalam penelitian ini sejalan dengan pendapat Shoimin (2014:108) yang menyatakan bahwa model pembelajaran Numbered Heads Together (NHT) merupakan suatu model pembelajaran berkelompok yang setiap anggota kelompoknya bertanggung jawab atas tugas kelompoknya, sehingga tidak ada pemisahan antara siswa yang satu dan siswa yang lain dalam satu kelompok untuk saling memberi dan menerima antara satu dengan yang lainnya. Berdasarkan penelitian yang telah dilakukan, dalam belajar kelompok setiap anggota kelompok dapat memastikan untuk dapat mengerjakan soal yang telah diberikan, adapun salah satu dari anggota kelompok yang belum bisa mengerjakan akan menjadi tanggung jawab semua anggota kelompok untuk saling membantu dengan cara menjelaskan cara atau langkah-langkah untuk dapat menemukan jawaban yang tepat. Dengan ini, setiap siswa menjadi semangat untuk dapat mengerjakan soal tanpa bantuan dari anggota kelompok yang lain.

Berdasarkan refleksi pada siklus I, maka tindakan yang dilakukan dalam siklus II bertujuan untuk memperbaiki kekurangan pada siklus I, sehingga pada siklus II rata-rata peningkatan motivasi belajar siswa meningkat 23,25\%, semua siswa aktif dalam berdiskusi secara sungguhsungguh agar setaip anggota kelompok dapat mengerjakan dan memahami pertanyaan yang diberikan guru. Selain itu, pola interaksi antar siswa juga semakin meningkat karena siswa yang telah memahami soal bisa mengajari siswa yang belum mampu mengerjakan.

\section{TABEL 2}

PERBANDINGAN HASIL BELAJAR KONDISI AWAL, SIKLUS I DAN SIKLUS II

\begin{tabular}{|c|c|c|c|c|c|c|c|c|}
\hline \multirow[t]{2}{*}{ No } & \multirow[t]{2}{*}{$\begin{array}{l}\text { Ketun } \\
\text { tasan }\end{array}$} & \multirow[t]{2}{*}{ Nilai } & \multicolumn{2}{|c|}{$\begin{array}{c}\text { Kondisi } \\
\text { Awal }\end{array}$} & \multicolumn{2}{|c|}{$\begin{array}{c}\text { Siklus } \\
\text { I }\end{array}$} & \multicolumn{2}{|c|}{$\begin{array}{c}\text { Siklus } \\
\text { II }\end{array}$} \\
\hline & & & $\mathbf{F}$ & $\begin{array}{c}\mathbf{P} \\
(\%)\end{array}$ & $\mathbf{F}$ & $\begin{array}{c}\mathbf{P} \\
(\%)\end{array}$ & $\mathbf{F}$ & $\begin{array}{c}\mathbf{P} \\
(\%)\end{array}$ \\
\hline \multirow[t]{3}{*}{1} & \multirow[t]{3}{*}{ Tuntas } & $91-100$ & - & - & 2 & $10 \%$ & 9 & $45 \%$ \\
\hline & & $81-90$ & 4 & $20 \%$ & 6 & $30 \%$ & 6 & $30 \%$ \\
\hline & & $71-80$ & 2 & $10 \%$ & 4 & $20 \%$ & 3 & $15 \%$ \\
\hline \multirow[t]{7}{*}{2} & \multirow{7}{*}{$\begin{array}{c}\text { Tidak } \\
\text { Tuntas }\end{array}$} & $61-70$ & 2 & $10 \%$ & 5 & $25 \%$ & 2 & $10 \%$ \\
\hline & & $51-60$ & 5 & $25 \%$ & 2 & $10 \%$ & - & - \\
\hline & & $41-50$ & 3 & $15 \%$ & 1 & $5 \%$ & - & - \\
\hline & & $31-40$ & 4 & $20 \%$ & - & - & - & - \\
\hline & & $21-30$ & 2 & $10 \%$ & - & - & - & - \\
\hline & & $11-20$ & - & - & - & - & - & - \\
\hline & & $1-10$ & - & - & - & - & - & - \\
\hline \multicolumn{3}{|c|}{ Rata-rata } & \multicolumn{2}{|c|}{54,15} & \multicolumn{2}{|c|}{75,75} & \multicolumn{2}{|c|}{89,25} \\
\hline \multicolumn{3}{|c|}{ Nilai Tertinggi } & \multicolumn{2}{|c|}{85} & \multicolumn{2}{|c|}{95} & \multicolumn{2}{|c|}{100} \\
\hline \multicolumn{3}{|c|}{ Nilai Terendah } & \multicolumn{2}{|c|}{30} & \multicolumn{2}{|c|}{50} & \multicolumn{2}{|c|}{75} \\
\hline
\end{tabular}

Tabel 2 tentang perbandingan ketuntasan hasil belajar Matematika. Dapat diketahui bahwa terdapat 
peningkatan hasil belajar dari kondisi awal, siklus I ke siklus II. Pada hasil belajar kognitif kondisi awal 6 siswa (30\%) dikatakan tuntas, meningkat pada siklus I terdapat 12 siswa (60\%) tuntas dan pada siklus II terdapat 18 siswa (90\%) tuntas. Dengan nilai ratarata siklus I 75,75 mengalami peningkatan pada siklus II dengan nilai rata-rata 89,25. Dengan nilai terendah siklus I 50 siklus II nilai tertinggi 75 dan nilai tertinggi pada siklus I 95 siklus II nilai tertinggi 100.

Berdasarkan peningkatan hasil belajar pada pembelajaran matematika sejalan dengan pendapat yang di kemukakan oleh Ibrahim (200:18) mengenai manfaat yang diperoleh dalam menggunakan model pembelajaran kooperatif tipe Numbered Head Together (NHT) adalah dapat meningkatkan hasil belajar siswa serta membuat pemahaman siswa menjadi lebih dalam terhadap materi yang telah dipelajari. Sejalan dengan yang dikemukakan oleh Kristin (2016:91) bahwa baik tidaknya peningkatan hasil belajar siswa hanya didukung oleh kemauan siswa yang mau belajar dengan baik, tetapi metode pembelajaran yang digunakan guru juga sangat berpengaruh terhadap hasil belajar siswa. Meningkatnya hasil belajar siswa dari kondisi awal, siklus I dan sikus II terjadi karena metode pembelajaran yang digunakan guru berbeda dengan metode yang biasa digunakan oleh guru. Dengan ini kemauan belajar siswa juga meningkat karena siswa mampu menemukan metode yang baru dan menarik untuk dapat dengan mudah memahami pembelajaran yang disampaikan oleh guru.

\section{Pembahasan}

Dalam kegiatan pembelajaran dengan menggunakan model pembelajaran kooperatif tipe Numbered Head Together (NHT), siswa diharapkan mampu meningkatkan motivasi belajar dan hasil belajar. Motivasi belajar siswa dalam pembelajaran sangatlah dibutuhkan untuk meningkatkan hasil belajar siswa. Model pembelajaran kooperatif tipe Numbered Head Together (NHT) merupakan model pembelajaran dengan berkelompok atau berdiskusi kelompok yang bertujuan untuk menentukan jawaban yang paling tepat untuk dipresentasikan.

Menurut Ibrahim (200:18) penggunaan model pembelajaran kooperatif tipe Numbered Head Together (NHT) Pada pembelajaran matematika mampu meningkatkan motivasi belajar dan hasil belajar dengan menggunakan 4 fase dalam kooperatif tipe Numbered Head Together (NHT)sebagai berikut:

a. Fase 1 penomoran, yaitu guru membagi siswa menjadi beberapa kelompok atau tim yang beranggotakan 3-5 orang dan memberi nomor siswa dan setiap siswa dalam tim mempunyai nomor yang berbeda-beda sesuai dan jumlah siswa dalam kelompok

b. Fase 2 pengajuan pertanyaan, yaitu guru mengajukan pertanyaan kepada siswa sesuai dengan materi yang sedang dipelajari yang bervariasi dari yang spesifik hingga bersifat umum dan dengan tingkat kesulitan yang bervariasi dan siswa menyimak dan menjawab pertanyaan.

c. Fase 3 berfikir bersama, yaitu guru memberikan bimbingan bagi kelompok yang membutuhkan dan siswa berfikir bersama untuk menemukan jawaban dan menjelaskan jawaban kepada anggota dalam timnya hingga semua anggota mengetahui jawaban dadi masing-masing pertanyaan

d. Fase 4 pemberian jawaban, yaitu guru menyebutkan salah satu secara acak untuk menjawab pertanyaan dan siswa dari tiap kelompok yang bernomor sama mengangkat tangan dan menyiapkan jawaban untuk seluruh kelas kemudian berdiri atau maju kedepan untuk menjawab pertanyaan.

Model pembelajaran kooperatif tipe Numbered Head Together (NHT) ini digunakan peneliti untuk meningkatkan motivasi belajar dan hasil belajar siswa kelas IV dalam pembelajaran matematika. Hasil observasi yang telah dilakukan peneliti di kelas IV SD Negeri Genting 01, diketahui bahwa sebelum tindakan penelitian dilaksanakan terlihat adanya permasalahan dalam pembelajaran. Permasalahan yang terjadi adalah rendahnya motivasi atau minat siswa untuk mengikuti pembelajaran matematika yang diakibatkan oleh paradigma siswa yang telah menganggap bahwa matematika meruppakan pembelajaran yang paling sulit dan membosankan. Rendahnya motivasi siswa terhadap pembelajaran matematika berdampak terhadap rendahnya hasil belajar siswa pada pembelajaran matematika. Berdasarkan kondisi demikian, peneliti merasa diperlukan adanya tindakan perbaikan dalam proses pembelajaran untuk meningkatkan motivasi belajar dan hasil belajar siswa kelas IV SD Negeri Genting o1 dengan menerapkan model pembelajaran kooperatif tipe Numbered Head Together (NHT). Dilihat dari motivasi belajar pada kondisi awal terdapat 1 siswa (5\%) yang berada di kategori motivasi sangat tinggi dan 3 siswa (15\%) berada dalam kategori motivasi tinggi, 2 siswa (10\%) berada di kategori motivasi sedang dan 14 siswa (70\%) berada di kategori motivasi rendah. Hasil belajar pada kondisi awal tercatat 6 siswa (30\%) tuntas atau sudah mencapai KKM $\geq 70$ dan 14 siswa (70\%) belum tuntas atau belum mencapai $\mathrm{KKM}<70$. Berdasarkan data tersebut dapat dinyakatan bahwa motivasi belajar dan hasil belajar siswa masih dibawah indikator kinerja yang telah ditetapkan 
peneliti yaitu $80 \%$ mencapai $\mathrm{KKM}$ dan memiliki motivasi tinggi dalam mengikuti pembelajaran matematika. Dengan melihat kondisi yang demikian, peneliti memberi upaya dengan adanya tindakan yang dapat meningkatkan motivasi belajar dan hasil belajar siswa dalam pembelajaran matematika kelas IV SD Negeri Genting 01 yaitu dengan menggunakan model pembelajaran kooperatif tipe Numbered Head Together (NHT) sebagai solusi dari permasalahan tersebut.

Peneliti menggunakan model pembelajaran kooperatif tipe Numbered Head Together (NHT) sebagai pilihan yang tepat dalam mengatasi rendahnya motivasi belajar dan hasil belajar siswa dalam mengikuti pembelajaran matematika. Melalui model pembelajaran ini siswa belajar dalam kelompok dengan saling berinteraksi antara satu siswa dengan yang lainya untuk bekerja sama menentukan jawaban yang tepat. Kegiatan tersebut menjadikan siswa menjadi lebih aktif dalam pembelajaran sehingga dapat mendorong naiknya hasil belajar siswa. Berdasarkan tindakan yang telah dilaksanakan, meningkatnya motivasi belajar berbanding lurus dengan meningkatnya hasil belajar siswa dalam pembelajaran matematika.

Model pembelajaran ini digunakan untuk Siklus I dan Siklus II sehingga dapat diketahui meningkat atau tidaknya motivasi belajar serta hasil belajar siswa setelah dilaksanakannya model pembelajaran kooperatif tipe Numbered Head Together (NHT). Pada siklus I motivasi belajar siswa, rata-rata nilai motivasi belajar siklus I adalah 6o,7 dengan 6 siswa (30\%) kategori sangat tinggi, 4 siswa (20\%) kategori tinggi, 7 siswa (35\%) kategori sedang dan 3 siswa (15\%) dengan kategori rendah. Perolehan hasil belajar siswa dengan rata-rata 75,75 berdasarkan 12 siswa (60\%) mencapai KKM dan 8 siswa (40\%) belum mencapai KKM. Nilai tertinggi 95 dan nilai terendah 50. Berdasarkan hasil penelitian tindakan siklus I, telah menunjukkan peningkatan motivasi belajar dan hasil belajar siswa dengan pencapaian cukup baik. Akan tetapi peneliti masih berupaya untuk meningkatkan motivasi belajar dan hasil belajar siswa pada tindakan siklus II.

Pada pelaksanaan siklus II diperoleh data motivasi belajar siswa kelas IV SD Negeri Genting 01 pada pembelajaran matematika telah mengalami peningkatan yang signifikan. Pencapaian motivasi belajar siswa dengan nilai rata-rata 83,95 dengan 17 siswa (85\%) kategori sangat tinggi dan 3 siswa (15\%) dengan kategori tinggi. Ini menunjukkan bahwa peningkatan yang telah mencapai $\geq 80 \%$ siswa mempunyai motivasi belajar tinggi merupakan hasil yang ditentukan peneliti sesuai dengan indikator kinerja. Selain motivasi belajar siswa, hasil belajar siswa pun juga mengalami peningkatan pada siklus II yaitu 18 siswa (90\%) telah mencapai KKM $\geq 70$ dan 2 siswa (10\%) belum mencapai KKM atau $<70$. Berdasarkan data hasil belajar siswa, data tersebut telah memenuhi 80\% siswa mencapai KKM dari indikator kinerja yang telah ditentukan oleh peneliti.

Menurut Nur (2011:78) model pembelajaran NHT merupakan sebuah variasi diskusi kelompok dengan ciri khasnya adalah guru menunjuk seorang siswa untuk mewakili kelompoknya. Berdasarkan penelitian yang telah dilakukan, sesuai dengan langkah-langkah model pembelajaran NHT guru menunjuk salah satu siswa dari setiap anggota kelompok untuk maju mempresentasikan jawabanya secara langsung yaitu pada saat pembelajaran berlangsung dan tanpa diberitahu dahulu sebelumnya siapa yang akan ditunjuk. Sehingga model pembelajaran ini dapat menjamin keterlibatan semua siswa dalam pembelajaran serta dapat memotivasi siswa yang sebelumnya terlihat pasif, bermain sendiri dan malas mengikuti pembelajaran setelah menggunakan model pembelajaran kooperatif tipe Numbered Head Together (NHT) menjadi aktif untuk bertanya dan menyampaikan gagasan atau ide serta menjadi lebih semangat dalam mengikuti pembelajaran matematika.

Dari hasil penelitian selama pelaksanaan tindakan pada siklus I dan siklus II dengan menggunakan model pembelajaran kooperatif tipe Numbered Head Together (NHT) meningkatkan motivasi belajar dan hasil belajar siswa dengan perolehan nilai rata-rata mengalami peningkatan dalam setiap siklus. Siswa dapat memahami dan mengerti materi pembelajaran yang diberikan oleh guru, siswa juga menjadi aktif dalam pembelajaran serta menjadi lebih percaya diri dalam menyampaikan ide atau pendapatnya. Selain itu, interaksi antar siswa juga menjadi lebih baik. Penggunaan model pembelajaran kooperatif tipe Numbered Head Together (NHT) ini mampu mengubah paradigma siswa bahwa matematika bukanlah pembelajaran yang paling sulit dan membosankan, melainkan menjadi pembelajaran yang sangat menyenangkan dan menarik.

Berdasarkan penelitian yang telah dilakukan pada Siklus I dan siklus II terbukti jelas adanya peningkatan baik dari motivasi belajar maupun hasil belajar siswa kelas IV SD Negeri Genting 01 pada pembelajaran matematika dengan menggunakan model pembelajaran kooperatif tipe Numbered Head Together (NHT). Siswa yang sebelumnya malas untuk mengikuti pembelajaran matematika karena matematika merupakan pembelajaran yang paling sulit dan membosankan sehingga berdampak pada rendahnya hasil belajar siswa berubah menjadi sangat tertarik dapat mengikuti pembelajaran matematika dan hasil belajarnya pun juga mengalami peningkatan. 
Penelitian ini mempunyai kelebihan dibandingkan dengan beberapa penelitian yang relevan yang pernah dilakukan dengan menggunakan model pembelajaran kooperatif tipe Numbered Head Together (NHT) dapat menjadi solusi dari rendahnya motivasi belajar dan hasil belajar siswa serta menjadikan pengalaman yang pertama bagi siswa dan guru SD Negeri Genting 01 dalam menerapkan model pembelajaran ini. Selain itu, melalui model pembelajaran NHT juga dapat meningkatkan rasa percaya diri siswa untuk maju mempresentasikan hasil diskusi. Hal ini sesuai dengan pendapat Slavin (2005:30) kelebihan dari model pembelajaran kooperatif tipe Numbered Head Together (NHT) yaitu dapat meningkatkan prestasi belajar siswa, mampu memperdalam pemahaman siswa, menyenangkan siswa dalam proses pembelajaran, mengembangkan sifat positif siswa, mengembangkan sifat kepemimpinan siswa, mengembangkan rasa ingin tahu siswa, meningkatkan rasa percaya diri siswa, mengembangkan rasa saling memiliki serta mengembangkan ketrampilan siswa.

Melalui belajar kelompok dengan guru yang memilihkan kelompok serta pembagian nomor dan soal bagi setiap anggota kelompok pada pembelajaran matematika dengan materi menentukan keliling dan luas bangun datar seperti persegi, persegi panjang dan segitiga. dengan melalui model pembelajaran ini siswa dapat memahami cara menentukan keliling dan luas bangun datar tanpa harus dengan menghafalkan rumus tetapi hanya dengan melihat bangun datar dapat menentukan rumus yang akan diigunakan untuk menemukan luas dan keliling setiap bangun datar. Pemilihan anggota kelompok yang berbedabeda dalam setiap siklus juga dapat meningkatkan interaksi siswa supaya menjadi lebih aktif dalam belajar kelompok. Penggunaan model pembelajaran kooperatif tipe Numbered Head Together (NHT) ini telah disesuaikan dengan standar pross yang ada, sehingga memudahkan guru dalam menggunakan model pembelajaran kooperatif tipe Numbered Head Together (NHT) yang dapat memberikan pengalaman yang positif bagi siswa dan guru sehingga pembelajaran dapat terlaksana dengan baik dan bermakna sesuai materi yang telah diajarkan pada kelas IV SD Negeri Genting o1 Kecamatan Jambu Kabupaten Semarang.

\section{SIMPULAN DAN SARAN}

\section{Simpulan}

Hasil penelitian menunjukkan bahwa penggunaan model pembelajaran kooperatif tipe Numbered Head Together (NHT) dapat meningkatkan motivasi belajar dan hasil belajar. Di buktikan pada kondisi awal nilai rata-rata motivasi belajar siswa 43,15 dengan 1 siswa (5\%) dalam kategori sangat tinggi, 3 siswa (15\%) kategori tinggi, 2 siswa (10\%) kategori sedang dan 14 siswa (70\%) dengan kategori rendah, siklus I nilai rata-rata motivasi belajar siswa 60,7 dengan 6 siswa (30\%) kategori sangat tinggi, 4 siswa (20\%) kategori tinggi, 7 siswa (35\%) kategori sedang dan 3 siswa (15\%) dengan kategori rendah dan pada siklus II nilai ratarata motivasi belajar siswa 83,95 dengan 17 siswa (85\%) kategori sangat tinggi dan 3 siswa (15\%) dengan kategori tinggi. Penelitian dengan menggunakan model pembelajara kooperatif tipe Numbered Head Together (NHT) juga dapat peningkatkan hasil belajar siswa Siklus I 60,7\% dan Siklus II 83,95\% Rata-rata nilai hasil belajar siswa pada kondisi awal 54,15 dengan nilai tertinggi 85 terendah 30, Rata-rata nilai hasil belajar siswa pada Siklus I 75,75 dengan nilai tertinggi 95 terendah 50, Rata-rata niai hasil belajar siswa pada Siklus II 89,25 dengan nilai tertinggi 100 terendah 75.Pencapaian hasil belajar siswa ini menunjukkan kondisi yang telah mencapai 80\% siswa mencapai KKM berdasarkan indikator kinerja yang telah ditetapkan oleh peneliti.

\section{Saran}

Keberhasilan dalam penelitian tindakan kelas (PTK) yang hendaknya dijadikan sumber referensi bagi guru untuk menerapkan model model pembelajaran kooperatif tipe Numbered Head Together (NHT) dalam proses pembelajaran untuk menambahkan pengetahuan dan ketrampilan guru dalam mengatasi permasalahan yang timbul dalam proses kegiatan belajar mengajar matematika. Siswa yang memiliki motivasi yang rendah dan nilai yang masih di bawah KKM pada pembelajaran matematika menjadi lebih fokus dalam mengikuti pembelajaran menggunakan model pembelajaran kooperatif tipe Numbered Head Together (NHT). Sekolah dapat memberikan sosialisasi kepada guru untuk menggunakan berbagai model pembelajaran untuk menciptakan pembelajaran dikelas menjadilebih baik juga untuk meningkatkan mutu dan kualitas lulusan sekolah.

\section{UCAPAN TERIMA KASIH}

Penulis mengucapkan terima kasih kepada Allah SWT karena atas berkat Rahmat dan Hidayahnya penulis dapat menyelesaikan penelitian ini tanpa suatu halangan apapun. kepada semua pihak yang sudah terlibat dan membantu dalam proses penelitian, terutama kepada orang tua yang telah memberikan dorongan dan doa, kepada dosen pembimbing dan kepada semua temanteman. Terima kasih juga kepada SD Negeri Genting 01 yang telah memberikan izin penelitian kepada penulis. 


\section{DAFTAR PUSTAKA}

[1] Anugraheni, I. (2018). Meta Analisis Model Pembelajaran Problem Based Learning dalam Meningkatkan Ketrampilan Berpikir Kritis di Sekolah Dasar [A Meta-analysis of Problem-Based Learning Models in Increasing Critical Thinking Skills in Elementary Schools]. Polyglot: Jurnal Imliah 14(1), 9-18.

[2] Anugraheni, I. (2017). Penggunaan Portofolio Dalam Perkuliahan Penilaian Pembelajaran. Jurnal Pendidikan Dasar Perkhasa, 3(1), 246-258.

[3] Arikunto, Suharsimi. 2010. Prosedur Penelitian Suatu Pendekatan Praktik. Jakarta: Rineka Cipta

[4] Badan Standar Nasional Pendidikan. 2006. Kurikulum Tingkat Satuan Pendidikan Mata Pelajaran Matematika. Jakarta: BSNP

[5] Boeree, George. 2008. Metode Pembelajaran \& pengajaran (terjemahan) Yogyakarta: AR-RUZZ MEDIA

[6] Depdiknas. 2006. Kurikulum Tingkat Satuan Pendidikan (KTSP). Bahan Presentasi. Jakarta: Departemen Pendidikan Nasional, Badan Penelyian dan Pengembangan Pusat Kurikulum (Puskurlitbang)

[7] Djamarah, Syaiful Bahri. 2011.Psikologi Belajar. Jakarta: Rineka Cipta

[8] Ibrahim, Muslimin, dkk. 200o. Pembelajaran Kooperatif. Surabaya: UNESA

[9] Kristin, F. (2016). Analisis Model Pembelajaran Discovery Learning dalam Meningkatkan Hasil Belajar Siswa SD.Jurnal Pendidikan Dasar Perkhasa, 2(1).

[10] Kristin, F. Penerapan Model Pembelajaran Kooperatif Tipe Number Heads Together Berbantuan Media Gambar Dalam Meningkatkan Motivasi Dan Hasil Belajar Ips Siswa Kelas IV Oleh Yunida Ika Nursanti.

[11] Kristin, F. (2016). Pengaruh Penerapan Model Pembelajaran Berbasis Budaya (Pbb) Terhadap Hasil Belajar Ips Dan Keaktifan Siswa Kelas Iv Sd Negeri o1 Tridarma Wirajaya. Elementary School (Jurnal Pendidikan dan Pembelajaran Ke-SD-an), 3(1).

[12] Prastomo, N. (2015). Peningkatan Motivasi Dan Prestasi Belajarmatematika Siswa Kelas Iv Sd Negeri Kepatihan Purworejo Dengan Metode Pembelajaran Cooperative Learning Tipe Nht (Numbered Head Together) Tahun Ajaran 2013/2014. EKUIVALEN-Pendidikan Matematika, $17(1)$.

[13] Slavin, E. Robert. 2005. Cooperative Learning Teori, Riset dan Praktik. Bandung: Nusa Media 